ANTHRopological ReVieW

Available online at: https://doi.org/10.18778/1898-6773.85.1.03

\title{
Case study: trepanation or injury? An example of an early medieval skull from Płock (Poland)
}

\author{
Aleksandra Partyńska, Daria Gromnicka \\ Department of Anthropology, Institute of Environmental Biology, \\ Wrocław University of Environmental and Life Sciences
}

\begin{abstract}
The aim of the study was to analyze a skull found in ossuary material in Płock, dated between the 16th and 19th centuries. The skull was subjected to a comprehensive anthropological analysis due to the number of pathological changes occurring to it. These changes testify to both the diseases experienced by the individual and the acquired bone injuries. The study aimed to find out whether the pathological changes on the skull appeared as a result of the injury or intentional trepanation. The examined skull shows three injuries, of which only one may resemble trepanation processes.

Comparative analysis of the skull showed that the observed marks were generated ante-mortem. The presence of compact regenerated bone tissue with a significant thickness attests to this statement. Based on the trauma marks, it was determined that two of them (" $\mathrm{A}$ " and " $\mathrm{B}$ ") had been struck by a sharp-edged instrument. They do not, however, match any known trepanation techniques. They should be categorized as purposeful injuries that are not trepanations, based on the proportions and shape of the incisions, as well as the comparative study. The " $\mathrm{C}$ " trace, when examined and compared to the literature, appears to be an oval depression caused by an impact with a blunt-edged object rather than a healed trepanation mark.
\end{abstract}

KeY WORDs: trepanation, injury, trauma, skull, modern, Płock, palaeopathology 


\section{Introduction}

Palaeopathology derives from three fields of knowledge: anthropology, medicine, and archeology (Gładykowska-Rzeczycka 1993). The diseases observed on the skeletal material include developmental changes, injuries, specific and non-specific inflammatory diseases, degenerative changes, disorders of the endocrine system, metabolic disorders and neoplastic changes (Gładykowska-Rzeczycka 1978). The afore mentioned fields allow for a more detailed analysis of historical populations and, together with other anthropological features, reveal an image of the living conditions of the past.

Traumatic bone injuries are one of the most important palaeopathological data (Owens 2007). They can be a consequence of accidental or deliberate actions. The first of the injuries mentioned above may be work related or to lifestyle factors, while deliberate injuries are the result of confrontational combat, robbery, execution or surgery (e.g. trepanation, amputation). Therefore, injuries are aprimary sources of data providing information related to interpersonal violence in past populations. Injuries may be antemortem when the subject has survived the injury or perimortem when the injury was fatal to the victim or occurred just before his death.

Skull injuries can be divided into many types, including active and passive (Teresiński 2002). This division is established on the basis of their location in relation to the so-called the "hat brim line", i.e. the hypothetical plane of the widest circumference, at the height of a hat's brim. All injuries above this line are considered passive injuries, i.e. those resulting from a fall, while those in the vicinity of this line and below it, are considered active. It should be noted that this criterion can be used when falling from the so-called 'your own height'. The nature of skull fractures depends more on the speed and energy of the injury than on the size of the tool inflicting the blow. Tomasz Kozłowski (1993) states that out of the 578 examined skulls, $5.4 \%$ have visible injuries. Moreover, they are more common on the left side of the skull. He noted a higher frequency of injuries on the parietal bones (almost half of the cases) and the frontal bones (over 25\%), followed by the nasal, temporal and occipital bones. In male skulls, cuts were dominant, followed by indentations, while in females it was the opposite, albeit, the differences between the frequencies were small. Post-traumatic conditions showing healing features accounted for over $90 \%$ of all injuries. One skull showed signs of trepanation.

Trepanation is a procedure that has been carried out since Neolithic times and involves making a hole in the skulls' cranial vault along with the removal of a part of the bone. Trepination has been used within the ritual context, as well as in therapy. The most probable reason for the use of trepanation was to relieve chronic headache, migraines and epilepsy (Negahnaz et al. 2015). Trepanations were characterized by the level of post-surgery survival that varied depending on the country and epoch (approximately $25 \%$ in Great Britain during the Iron Age, $78 \%$ in Switzerland at the same time, $72 \%$ in the Iron Age, and $50 \%$ in the early Middle Ages). Trepanations were performed on all continents, of which in Europe most of the skulls with post-trepanation traces were found in France, from where this custom spread to Eastern Europe in the Neolithic. Polish literature provides information on at 
least 50 trepanated skulls from Poland (Kozłowski 2012).

Majchrzak and Olender (2015), in their work on trepanation of Andean skulls, define four methods of opening skulls (after Lisowski: 1967): a) cutting lines to create a square or rectangular hole in the bone, b) scraping the bone to obtain a hole, which was the slowest, but at the same time the most accurate and safest method, c) drilling a hole or a series of small holes in the skull, which was used to break off a piece of the skull, d) gouging (sawing) cutting out a fragment of the bone in a circular. According to the authors, most trepanations were performed on the occipital bone, and on the left and middle frontal and parietal bones. Drilling at the skull base, as well as in the temporal bones was avoided. Lorkiewicz et al. (2018) mention surgical therapy which was used to treat head injuries as the goal of trepanation procedures.

The aim of the study was to analyze traces of intentional surgeries on a specific skull. Additionally, attempts were made to determine whether they were remnants of injuries or trepanations to the skull.

\section{Materials and methods}

The skull was found in an ossuary in Płock material dated between the 16th and 19th centuries. The ossuary was created as a result of moving the cemetery due to the construction of a bridge over the Vistula in the period preceding World War II. It presents a number of pathological changes, which testify to both diseases suffered by the individual and acquired bone injuries.

The research included the assessment of the sex of the subject (Steckel et al. 2005; Malinowski and Bożiłow 1997). Skull measurements were made using the Martin technique (Martin, Saller 1957), using standard measuring equipment twice, and the result was averaged. On their basis, the craniometric indicators were calculated (Malinowski and Bożiłow 1997). The characteristics of pathological changes were determined in accordance with the guidelines of Gładykowska-Rzeczycka (1976) and Ortner's atlas (1998). In addition, measurements of the found traces were made in order to determine their extent.

\section{Results}

The skull was preserved in very good condition, without the mandible (Calvarium). Postmortem lesions of the skull base and left zygomatic arch, as well as loss of incisors and canines without signs of obliteration of the alveolar sockets were noted.

Dimorphic features (in particular, clearly marked smoothness, no marked frontal and parietal nodules, the shape of the eye sockets and their rounded upper edge, as well as the massiveness of the mastoid process and strongly pronounced supraorbital arches) indicate that the examined skull belonged to a man. On the basis of obliteration of cranial sutures and traces of tooth wear, the age of the individual was determined as maturus/ senilis.

Twenty-five brain and craniofacial measurements were performed and averaged results are presented (tab. 1). Some of them are burdened with a higher risk of error due to the degree of obliteration of the individual's sutures. This applies to the ba-b measurement, which has a strongly approximate bregma point. It is similar with the meas- 
urement of co-co due to signs of over- the nasal spine. Part of the dimensions, growth of the coronary suture. In the including the total height of the skull, case of the n-ns value, the measurement could not be measured due to the lack uncertainty results from the chipping of of a mandible.

Table 1. Measurements of the skull

\begin{tabular}{|c|c|c|}
\hline No. & Measurement & $\mathrm{mm}$ \\
\hline 1 & g-op & 187 \\
\hline 2 & $\mathrm{n}-\mathrm{b}$ & 150 \\
\hline 3 & i-o & 38 \\
\hline 4 & n-ba & 115 \\
\hline 5 & ba-o & 37 \\
\hline 6 & ba-b & $138^{\star}$ \\
\hline 7 & eu-eu & 139 \\
\hline 8 & ast-ast & 115 \\
\hline 9 & $\mathrm{ft}-\mathrm{ft}$ & 99 \\
\hline 10 & co-co & $115^{\star}$ \\
\hline 11 & au-au & 110 \\
\hline 12 & mst-mst & 111 \\
\hline 13 & The width of the foramen magnum fol-fol & 30 \\
\hline 14 & Horizontal circcumference & 506 \\
\hline 15 & arch n-o & 300 \\
\hline 16 & arch n-b & 130 \\
\hline 17 & n-pr & 75 \\
\hline 18 & n-ns & $54^{\star}$ \\
\hline 19 & pr-ba & 101 \\
\hline 20 & ol-sta & 40 \\
\hline 21 & ek-ek & 97 \\
\hline 22 & $\mathrm{mf}-\mathrm{mf}$ & 18 \\
\hline 23 & mf-ek & P - $49 \mathrm{~L}-45$ \\
\hline 24 & The height of the eye socket sbk-spa & $P-35 L-35$ \\
\hline 25 & apt-apt & 28 \\
\hline
\end{tabular}

* - uncertain measurement

The performed measurements were used to calculate the craniometric indicators (Table 2). The subject had a long and quite narrow orthognathic skull, with a wide forehead, a narrow occipital opening, and a wide nose. The eye sockets were characterized by asymmetric size, with the right socket being in the low category and the left socket in the medium height category. 
Table 2. Craniometric indicators

\begin{tabular}{|c|c|c|c|}
\hline Indicator & Equation & Result & Description \\
\hline Width and length & eu-eu/g-op ${ }^{\star} 100$ & 74,33 & dolichokranius \\
\hline Height and length & ba-b/g-op ${ }^{\star} 100$ & 73,80 & Orthokranius \\
\hline Height and width & ba-b/eu-eu ${ }^{\star} 100$ & 99,28 & Akrokranius \\
\hline $\begin{array}{l}\text { Average height and width } \\
\text { of the skull Hrdlicki-Kocki }\end{array}$ & ba-b/(g-op+eu-eu)/2*100 & 84,66 & $\begin{array}{l}\text { Mesosemic by Steward, Kocka and } \\
\text { Vallois, megasemic by Hrdlicka }\end{array}$ \\
\hline Fronto-parietal & $\mathrm{ft}-\mathrm{ft} / \mathrm{eu}-\mathrm{eu}{ }^{\star} 100$ & 71,22 & eurymetopus \\
\hline Foramen magnum & fol-fol/ba-o ${ }^{\star} 100$ & 81,08 & narrow \\
\hline Orbital fissure of the skull & sble-spa/mf-ek 100 & $\begin{array}{l}\mathrm{R}-71,43 \\
\mathrm{~L}-77,77\end{array}$ & $\begin{array}{l}\mathrm{R} \text { - chamaekonch } \\
\mathrm{L} \text { - esokonch }\end{array}$ \\
\hline Nose, skull & apt-apt/n-ns ${ }^{\star} 100$ & 51,85 & chamaerrhinus \\
\hline Maxillary & $\mathrm{pr}-\mathrm{ba} / \mathrm{n}-\mathrm{ba}^{\star} 100$ & 87,83 & orthognath \\
\hline
\end{tabular}

The skull depicted 3 trauma marks. In order to determine whether the analysed traces were traumas or trepanations, an additional computed tomography was performed (photos 4, 5 and 6). The examination consisted of scanning the skull and creating several hundred layers, which were then downloaded to a computer and analysed.

The first of these, injury ' $\mathrm{A}$ ' was $\mathrm{U}$-shaped. It ran along the region of the coronal suture, then turned at a right angle and continued along the sagittal suture where it bent halfway along the left parietal bone (Fig. 1 and 2). It was $87 \mathrm{~mm}$ long and $74 \mathrm{~mm}$ wide in total. It was inflicted from above at an angle and caused a skull fracture, the remnant of which is a fissure $34 \mathrm{~mm}$ long and $6 \mathrm{~mm}$ thick. The location of the trace corresponds to the most common injury sites (left side of the skull, parietal bone and frontal bone). However, it was made with great force from the medial side towards the external side. The fact that it was an extensive, fairly wide wound also supports the classification of the mark as an injury, which may indicate that it was inflicted with a sharpedged object. Its shape also cannot be attributed to any trepanation technique. The CT scan (Fig. 5) shows bone thickening and compaction characteristic of healing marks leading to partial occlusion of the hole.

Trace " $\mathrm{B}$ " is located on the left side of the occipital bone of the examined skull and overlaps the cephalic suture that connects the occipital bone with the parietal bones (Fig. 3 and 8). It is $71 \mathrm{~mm}$ long and $41 \mathrm{~mm}$ wide. The object that caused the mark made contact with the bone from above and caused a deep incision $7 \mathrm{~mm}$ thick with an opening length of $45 \mathrm{~mm}$. This is an area where trauma rarely occurs. The incision of the bone was made with great force, penetrating well into the occipital bone, but not causing a skull fracture. This, however, does not exclude the classification of the mark as a post-operation wound. It is possible that the wound was made with a surgical instrument in order to, for example, decompress a hematoma 
or equalize intracranial pressure. Nevertheless, it was not a post-trepanation wound, as evidenced by the shape of the opening. The CT scan which was performed (Fig. 4 and 5) shows evidence of wound healing - visible traces of thickening and densification of bone tissue, which caused a significant portion of the hole to be sealed up.

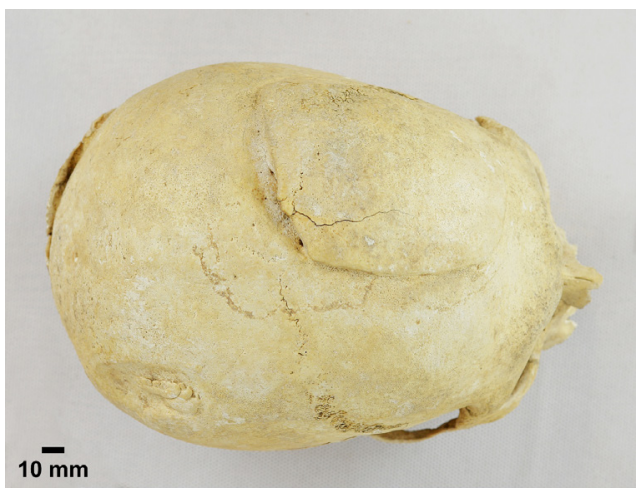

Fig. 1. Trace ' $\mathrm{A}$ ' on the frontal and parietal bone seen from above (superior).

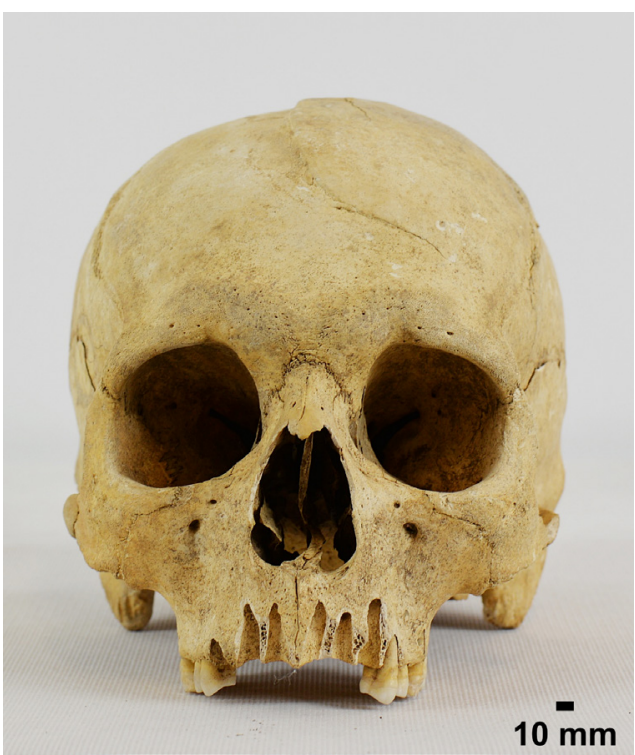

Fig. 2. Trace 'A' on the left frontal and parietal bone seen from the anterior side.

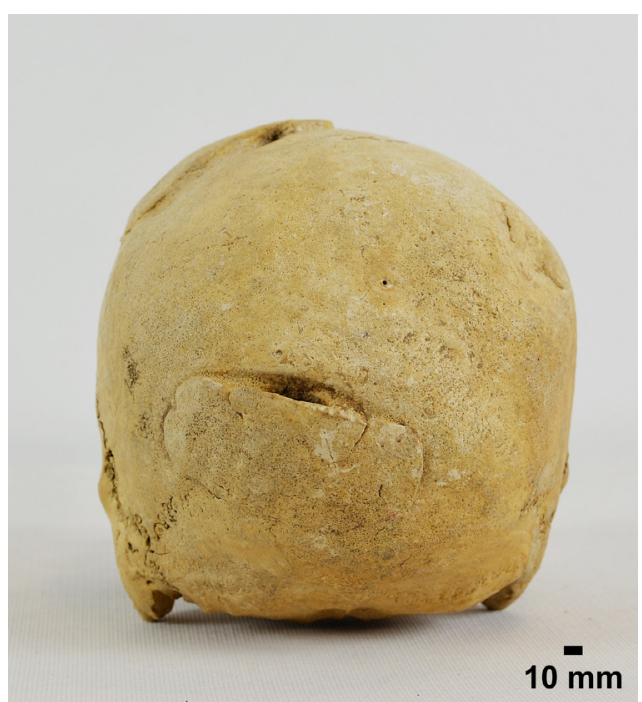

Fig. 3. Trace "B". - incision on the occipital bone seen from behind (posterior).

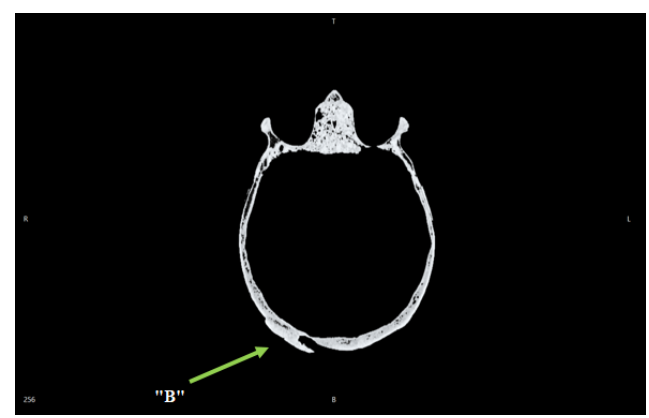

Fig. 4. Section of the skull in the transverse plane (transversum). Visible hollow in the skull at the site of trace " $\mathrm{B}$ " and signs of wound healing.

The third element is an oval scar trace. It is located approximately in the middle of the right parietal bone, above the almost completely obliterated scale suture (Fig. 6 and 8). It is $45 \mathrm{~mm}$ long and $35 \mathrm{~mm}$ wide. The scar could have been caused by the use of a blunt-edged tool or a cicatrized post-trrepanation hole. There were no traces of a fracture of the skull bone and no concentric inward healing characteristic of trepanations 
performed using the drilling technique, which could have been indicated by the shape of the injury. The observed trace was depressed and uniformly healed, which was confirmed by the CT scan (Fig. 7). This phenomenon indicates that for this individual the fracture did not prove to be fatal. It also shows the growth of bone tissue.

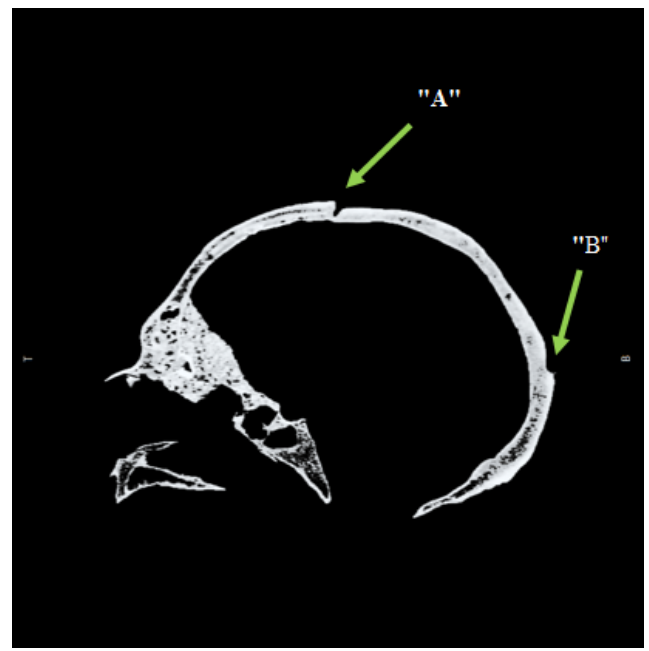

Fig. 5. Section of the skull in the sagittal plane from the left side. Visible hollow in the skull at the site of mark " $\mathrm{A}$ " and signs of healing of wounds "A" and "B".

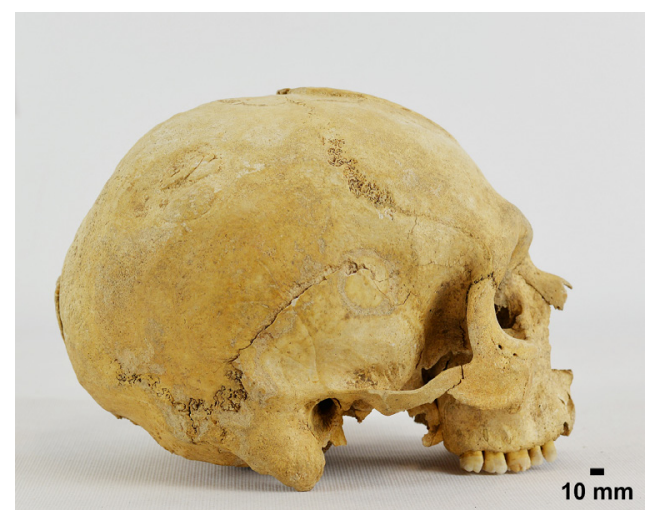

Fig. 6. Trace ' $\mathrm{C}$ ' - indentation on the right parietal bone (dexter) visible from the side.

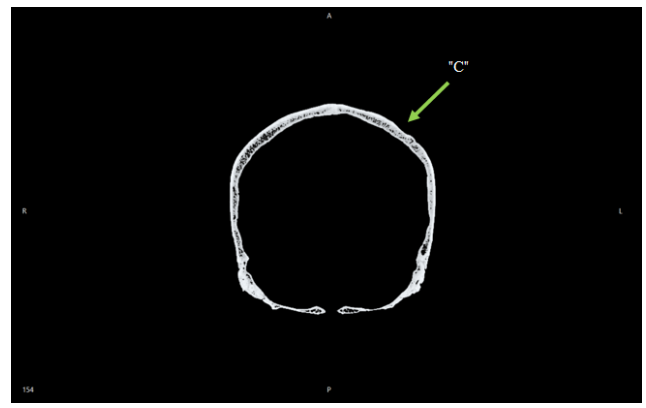

Fig. 7. Section of the skull in the posterior side. Visible hollow in the right side coresponding to mark " $\mathrm{C}$ ". Visible signs of bone tissue thickening indicative of wound healing.

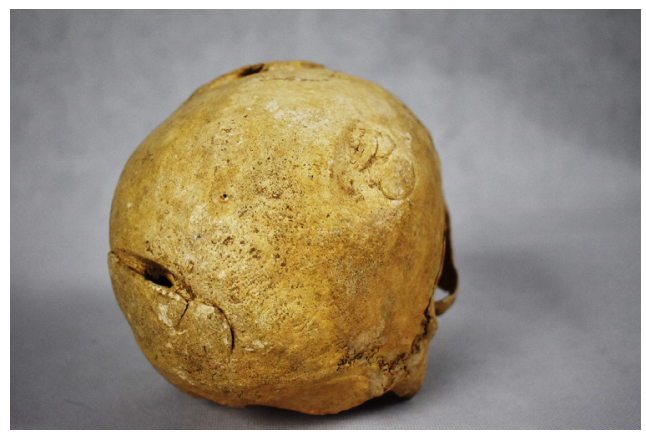

Fig. 8. Traces ' $\mathrm{B}^{\prime}$ and ${ }^{\prime} \mathrm{C}$ ' visible from the rear-lateral (dexter) side. Fragment of the " $\mathrm{A}$ " mark on the front left side of the skull is also visible.

\section{Discussion}

This study attempted to determine what factors may have contributed to the appearance of the observed changes to the skull in question. Three traces were identified. Each was described on the basis of 3D photographs and scans as well as CT images. The observations were compared with examples from the literature.

The study of Brzobohata et al. (2017) where they described a skeleton that belonged to a woman between 20 and 25 years of age, in which there was an oval depression on the right parietal bone was 
used as comparative material. It was probably formed by a blow from a sharp object, probably an axe. Based on features considered diagnostic for this type of injury, it was determined to have formed around the time of death. It showed no signs of healing or infection, suggesting a direct cause of death for this woman (intracranial bleeding). It is somewhat similar to the shape of the "B" injury on the occiput of the studied individual, but is much shallower and narrower.

A similar case, which was used in the comparative analysis of injuries on the skull of a male from Plock, was described by Nagar et al. (2018). In their work they analyzed 4 injuries located on the skull of a male individual aged $30-40$ years, 3 of which were peri-mortem, with the last blow being the immediate cause of death of the individual. The injuries were located near the midline of the frontal bone (near the coronal suture), posterior to the parietal bone, and posterior to the sagittal suture. The first injury was determined that it was inflicted by a sharp instrument falling from above; the second injury was speculated to be a force injury inflicted at an oblique angle also by a sharp instrument - probably the same one. The third injury was caused by a blow to the back of the skull. It was presumed to have been inflicted with a sword, as evidenced by the lack of serrations on the mark. The largest injury ran from the left parietal bone cutting through the sagittal sutures and scapular sutures to the base of the zygomatic process of the right temporal bone. It was an open cut which indicated a blow delivered with a sword from the upper right side, which was assumed as being the immediate cause of this individual's death. These marks differ from the " $\mathrm{A}$ " and " $\mathrm{B}$ " injuries analyzed in this paper in the depth and width of the cuts. How- ever, they were similar in shape suggesting a high force pressure with a sharp-edged instrument.

Another example are the 5 skulls deposited in the Hungarian Museum of Natural History (Marton et al. 2016). On the first skull, a puncture wound was observed on the frontal bone, which also crosses the upper orbital wall. It may be classified as an arrow-inflicted mortal wound, as no signs of healing were observed at the edges. On the second skull, a defect was found above the orbit and a thickening on the eyebrow arch, but the victim survived the injury as healing marks were visible. This skull also had an injury on the parietal side, which was not fatal neither. The third skull had traces of being struck by a sharp instrument descending from above, passing through the right parietal bone and temporal bone to the frontal bone. This skull also had healing marks in the form of rounded bone edges, which precludes the injury from being considered fatal, although, they had not been fully healed, so death may have occurred some time after the event. The fourth example was a chop wound running in a lower to upper direction with no signs of healing, confirming that this was a fatal blow. The last skull described in this publication bore signs of a chop wound that caused the bony edges to be raised. These were rounded and healed at the edges, indicating that the blows were not fatal. From the examples presented in the publication, traces similar to those observed in the individual from Plock were found on skull number three, where the blow caused the skull fragment to split and shift. Morover, the top edge resembled trace "B" on the occipital (which, however, did not cause the skull fragment to split). A similarity to trace " $\mathrm{A}$ " on the skull from Płock was also evident on skull numer 
four, on which, however, the trace was very thin despite its considerable length.

Steyn et al. (2009) in their work on ante-mortem trauma describe a case of a healed cut wound located on the right frontal bone. It is much wider and shallower than marks " $\mathrm{A}$ " and " $\mathrm{B}$ ", but has a similar shape.

Also, Nerlich et al. in their 2015 paper described an interesting case of a skull mark that most likely came from an injury caused by a sharp-edged instrument. This trace is similar to trace " $\mathrm{A}$ " on the skull from Plock. It had a similar course, but led to a complete separation of the vault from the rest of the skull and does not contain any signs of healing.

Examples of trepanation include the skulls described by Lorkiewicz et al. (2018). The skulls belonged to 6 adult males. The first one had a trepanation hole in the upper part of the vault, at the cranial suture, with perpendicular (except for the anterior oblique part) walls obliterated by healing. They indicate sawing as this technique is for making the hole. On the second skull, on the right frontal shell and parietal bone, a large oval hole with traces of healing was found, surrounded by a wide ring of rubbed bone, indicating the use of the scraping method. On the third skull, a pair of nearly oval post-traumatic marks separated by a small bone bridge was visible on the right parietal bone. In both cases, the bone was excised with a sharp instrument positioned perpendicular to the skull surface, probably to drain some pus. Morover, there were two additional defects on the left parietal bone that may also be trepanation marks made by drilling. All of the above-mentioned lesions were fully healed. Another skull had a large, oval-shaped hole in the left parietal bone made probably by a mixed technique, in which the left and upper left portions were sawn out, while the rest were made by scraping or extracranial drilling. On skull number five, there were two holes on the left half of the cranial vault: one was large and L-shaped, while the other was smaller and oval-shaped. The cranial vault showed two healed lesions made with a sharp instrument. The larger hole was made at the site of an extensive fracture by removing bone fragments and cleaning the edges. The second, smaller hole, most likely represents a typical trepanation made with a sawing technique. The right side of the vault of the last skull showed evidence of extensive blunt force trauma in the form of a circular, depressed area surrounded by a line of concentric fracture and three radiating fractures. All of these lesions were fully healed. There was an oval, funnel-shaped opening adjacent to the frontal bone defect. The most likely interpretation of this lesion was trepanation performed by a combination of drilling and scraping. The alternative diagnosis of this lesion as blunt force trauma was less likely given the CT images confirming that the bone was removed from the site rather than indented inward.

However, all of these injuries differ significantly in the shape and edges of the openings from the studied skull, making it less likely that the analyzed injuries could be classified as trepanation. The blunt trauma trace from the literature was also not similar to the " $\mathrm{C}$ " trace.

\section{Conclusion}

Comparative analysis of the skull showed that the observed marks were formed ante-mortem. This is evidenced by the presence of compact regenerative bone tissue of considerable thickness. 
Based on the analysis of the trauma marks, it was concluded that two of them (" $\mathrm{A}$ " and " $\mathrm{B}$ ") were inflicted with a sharp-edged object. At the same time, they did not match any known trepanation techniques. Considering the dimensions and shape of the incisions as well as the comparative analysis, they should be classified as intentional injuries which are not trepanations. Observation of the "C" trace and its comparison with the literature indicates that it resembles an oval depression resulting from an impact with a blunt-edged instrument rather than a healed trepanation mark. However, the CT scan did not show this.

In conclusion, the analyses which were carried out are an important part of the research on distinguishing trepanation marks from trauma. They made it possible to determine the nature of the observed changes with a fairly high probability.

\section{Akcnowledgement}

This publication was financed by the Minister of Science and Higher Education (Grant No DNK/SP/463728/2020): Excellent Science - Support for scientific conferences. Funeralia Gnieźnieńskie Man in the perspective of interdisciplinary research.

\section{Authors' contribution}

Daria Gromnicka (50\%): prepared a draft, collected and analysed data (including anthropometric measurements, CT scans and photographs), collected references.

Aleksandra Partyńska (50\%): designed the study, prepared a draft, collected references.

\section{Conflict of interests}

Authors declare none conflict of interests

\section{Corresponding author}

Daria Gromnicka, Department of Anthropology, Institute of Environmental Biology, Wrocław University of Environmental and Life Sciences, Kożuchowska St. 5, 51-631 Wrocław, Poland.

E-mail: daria.gromnicka@gmail.com

\section{References}

Brzobohata H, Sumberova R, Vortrubova-Dubaka J, Vanek D. 2017. A case of sharp force trauma to the skull of female buried within a Neolithis rondel, Kolin (Czech Republic). Coll Antropol 41(3):287-303.

Gładykowska-Rzeczycka J. 1976. Zmiany w układzie kostnym ludności ze średniowiecznych cmentarzysk, w: Badania populacji ludzkich na materiałach współczesnych i historycznych. Seria Antropologia 4. Poznań: UAM. 85-103.

Gładykowska-Rzeczycka J. 1978. Częstość występowania niektórych zmian chorobowych widocznych w obrębie układu kostnego na przestrzeni tysiącleci. Przegląd Antropologiczny 44(2):409-14.

Gładykowska-Rzeczycka J. 1993. Paleopatologia - rozwój, osiągnięcia i zamierzenia. Przegląd Antropologiczny 56(1-2):169-76.

Kozłowski T. 2012. Stan biologiczny i warunki życia ludności in Culmine na Pomorzu Nadwiślańskim (X-XIII wiek). Toruń: Wydawnictwo UMK.

Kozłowski T. 1993. Charakterystyka urazów układu kostnego ludności pochowanej na cmentarzysku w Grucznie (XI - XIV w.). Przegląd Antropologiczny 56(1-2):177-89. Lisowski FP. 1967. Prehistoric and early historic trepanation. In: DR Brothwell, and AT Sandison. Diseases in antiquity: a sur- 
vey of the diseases, injuries, and surgery of early populations. Springfield, Illinois (USA): Charles C Thomas Pub Ltd.

Lorkiewicz W, Mietlińska J, Karkus J, Żądzińska E, Jakubowski JK, Antoszewski B. 2018. Over 4,500 years of trepanation in Poland: From the unknown to therapeutic advisability. Int $\mathrm{J}$ Osteoarchaeol 28(6):626-35. https://doi.org/10.1002/ oa. 2675

Majchrzak Ł, Olender K. 2015. Trepanacje czaszki w starożytnych Andach Środkowych, Zeszyty Naukowe Towarzystwa Doktorantów UJ, Nauki Społeczne, 10(1). Kraków: Repozytorium UJ [In Polish].

Malinowski A, Bożiłow W. 1997. Podstawy antropometrii: metody, techniki, normy. Warszawa, Łódź: Wydawnictwo Naukowe PWN.

Martin R, Saller K. 1957. Lehrbuch der anthropologie. Stuttgar: Gustav Fischer Verlag.

Marton N, Marcsa B, Pap I, Szikossy I, Kovacs B, Karlinger K, et al. 2016. Forensic evaluation of crania exhibiting evidence of sharp force trauma recovered from archeological excavations. Austin J Forensic Sci Criminol 2(2):1016.

Moghaddama N, Mailler-Burcha S, Karab CL, Jackowski FKC, Lösch S. 2015. Survival after trepanation-early cranial surgery from Late Iron Age Switzerland.
Int J Paleopathol 11:56-65. https://doi. org/10.1016/j.ijpp.2015.08.002

Nagar Y, Cohen H, Zissu B. 2018. Sharp force trauma to a 1000 -year-old skull from the Jerusalem mountains. Int J Osteoarcheol. https://doi.org/10.1002/oa.2716

Nerlich AG, Riepertinger A, Gillich R, Panzer S. 2015. Paleopathology and nutritional analysis of a South German Monastery Population. BioMed Research International ID 486467. https://doi. org/10.1155/2015/486467

Ortner D.J. 1998. Ortner's identification of pathological conditions in human skeletal remains. Academic Press.

Owens LS. 2007. Cranial trauma in the Prehispanic Canary Islands. Int J Osteoarchaeol 17: 465-78. https://doi.org/10.1002/oa.898 Steckel RH, Larsen CS, Sciulli PW, Walker PL. 2005. Data Collection Codebook. The Global History of Health Project. Columbus: The Ohio State University.

Steyn M, ISScan MY, Knock MD, Kranioti EF, Michalodimitrakis M, L'Abbé EN. 2009. Analysis of ante mortem trauma in three modern skeletal populations. Int J Osteoarchaeol 20: 561-71. https://doi. org/10.1002/oa.1096

Teresiński G. 2002. O ustalaniu okoliczności urazu głowy. Archiwum Medycyny Sądowej i Kryminologii 52:65-83. 